\title{
PEMBERDAYAAN SOSIAL EKONOMI PETANI DI PERKEBUNAN INTI RAKYAT: STUDI KASUS DI KISARAN, SUMATERA UTARA
}

\author{
Socio-Economic Empowerment of Farmers on Large Scale Plantation: \\ Case Study in Kisaran Subdistrict, North of Sumatra
}

\author{
Sismudjito*) $^{*}$ \\ Fisipol Universitas Sumatera Utara \\ *) E-mail: sismudjito_04@yahoo.co.id
}

\begin{abstract}
Indonesia has quite enormous potentials in plantation region, one of them is the Province of North Sumatra. The plantations in North Sumatra are distributed in some regions, one of them is Asahan Regency, especially in Kisaran Sub-District. There are two kinds of plantations i.e. the large-scale plantation and the PIR (Estate Smallholders). PIR consists of large scale plantation as nucleus and tradisional smallholders as plasma which allocates their lands manually and is labor intensive. The budidaya of land by traditionally has been inherited from generation to generation so that their farming activities have become routines and has not been able to achieve the maximum production. The efforts to improve the production should be accompanied by a development in human resources by means of empowerment. Supporting factors including providing capital togetherness, Science and Technology, guidance to all citizens as a means to increase production. Therefore, the development in human resources is meant to improve the plantation production through the society empowerment that goes simultaneously with the improvement in motivation.
\end{abstract}

Keywords: contract-farmaing, smallholder empowerment

\begin{abstract}
ABSTRAK
Indonesia memiliki potensi di bidang perkebunan yang cukup tinggi, salah satunya adalah wilayah Provinsi Sumatera Utara. Perkebunan di wilayah Sumatera Utara tersebar di beberapa daerah,salah satunya adalah daerah Kabupaten Asahan, khususnya di wilayah Kecamatan Kisaran. Ada dua jenis perkebunan yakni perkebunan berskala besar dan Perkebunan Inti Rakyat(PIR). Jenis perkebunan inti rakyat bersifat tradisional dan padat karya. Pembudidayaan lahan secara tradisionalyang diwariskan dari satu generasi ke generasi penerusnya, sehingga aktivitas mereka bertani atau berkebun bersifat rutinitas dan belum dapat mencapai produksi yang maksimal. Dalam upaya meningkatkan produksi harus diiringi dengan peningkatan Sumber Daya Manusia (SDM) melalui pemberdayaan. Faktorfaktor pendukung diantaranya memberikan modal kebersamaan, Ilmu Pengetahuan dan Teknologi (IPTEK), bimbingan kepada para warganya sebagai sarana untuk meningkatkan produksi. Dengan demikian, peningkatan sumber daya manusia ini berfungsi untuk meningkatkan produksi perkebunan melalui pemberdayaan masyarakat yang berjalan seiring dengan meningkatnya motivasi.
\end{abstract}

Kata kunci : pemberdayaan, perkebunan inti rakyat (PIR)

\section{PENDAHULUAN}

Usaha perkebunan merupakan bagian dari pertanian dalam arti yang luas. Usaha perkebunan yang ada di Indonesia dikenal dengan dua jenis usaha perkebunan, yakni perkebunan besar dan perkebunan kecil. Perkebunan dianggap berperan penting dalam memajukan perekonomian negara seperti meningkatkan PDB, menciptakan devisa negara, dan sebagai persediaan pangan negara (Raharto, 2016).Jenis perkebunan yang berskala kecil yang dikenal dengan Perkebunan Inti Rakyat (PIR) bersifat tradisional yang mengalokasikan lahannya dengan cara manual dan padat karya. Pengalokasian lahan dengan cara manual tersebut diwariskan dari satu generasi ke generasi penerusnya, sehingga aktivitas mereka bertani atau berkebun bersifat rutinitas dan belum dapat mencapai produksi yang maksimal.Paralel dengan hasil penelitian Wijaya, dkk(2009) dan Herawati (2011) bahwa implementasi program perusahaan Perkebunan Inti Rakyat (PIR-BUN) masih buruk.

Dalam skala mikro atau proyek, PIR-BUN adalah suatu proyek yang dilaksanakan dengan adanya pembangunan kebun inti dan plasma oleh perkebunan besar. Hubungan kerja sama antara perusahaan inti dengan petani peserta plasma diatur sebagai hubungan kerja formal dan tegas. Campur tangan pemerintah terbatas pada pengaturan, pengendalian, disamping pelayanan dan pemberian kemudahan atau bantuan sarana penunjang yang diperlukan khususnya bagi masyarakat petani peserta. Meskipun diakui bahwa tingkat pendapatan dan kesejahteraan petani peserta plasma dapat melebihi angka yang ditargetkan, akan tetapi total produksi dalam proyek tersebut tidak dapat dikatakan meningkat karena banyak petani tidak menyetorkan hasil kebun mereka kepada pihak perusahaan plasma. Kemandirian petani untuk menjadi petani yang mempunyai wawasan luas menjadi sosok petani yang mempunyai kultur teknik perkebunan modern tidak tercapai. Selama ini petani hanya memanfaatkan lahan perkebunan mereka yang telah dikelola oleh pihak perusahaan (Wijaya, dkk, 2009).

Realitas menunjukkan, terdapat beberapa kendala internal yang menggambarkan rendahnya tingkat produktivitas. Seiring dengan rendahnya tingkat produktivitas, secara kuantitatif luas wilayah perkebunan kecil atau inti rakyat dapat dilihat pada tabel sebagai berikut:

Sajian data BPS 2014 pada tabel 1 menunjukkan bahwa beberapaa wilayah Perkebunan Inti Rakyat (PIR) dari 20 Kabupaten, Asahan adalah salah satu Kabupaten yang memiliki 
Tabel 1. Beberapa luas wilayah Perkebunan Inti Rakyat di Sumatera Utara

\begin{tabular}{|c|c|c|c|}
\hline No & Wilayah & $\begin{array}{l}\text { Luas } \\
\text { (m2) }\end{array}$ & Keterangan \\
\hline 1 & Asahan & 72.337 & $\begin{array}{l}\text { Kawasan Obyek } \\
\text { Penelitian }\end{array}$ \\
\hline 2 & Batu Bara & 8.695 & \\
\hline 3 & Dairi & 164 & \\
\hline 4 & Deliserdang & 14.429 & \\
\hline 5 & $\begin{array}{l}\text { Humbang } \\
\text { Hasundutan }\end{array}$ & 287 & \\
\hline 6 & Karo & 1.337 & \\
\hline 7 & Labuhanbatu & 34.559 & \\
\hline 8 & $\begin{array}{l}\text { Labuhan Batu } \\
\text { Selatan }\end{array}$ & 42.658 & \\
\hline 9 & $\begin{array}{l}\text { Labuhan Batu } \\
\text { Utara }\end{array}$ & 68.161 & $\begin{array}{l}\text { Kawasan yang } \\
\text { Dikomparasikan }\end{array}$ \\
\hline 10 & Langkat & 45.413 & \\
\hline 11 & Mandailingnatal & 15.952 & \\
\hline 12 & Padang Lawas & 33.623 & \\
\hline 13 & $\begin{array}{l}\text { Padang Lawas } \\
\text { Utara }\end{array}$ & 26.722 & \\
\hline 14 & Pakpakbharat & 1.623 & \\
\hline 15 & Serdang Bedagai & 12.504 & \\
\hline 16 & Simalungun & 5.807 & \\
\hline 17 & Tapanuli Selatan & 5.158 & \\
\hline 18 & Tapanuli Tengah & $3.181 \mathrm{~s}$ & \\
\hline 19 & Tapanuli Utara & 38 & \\
\hline 20 & Tobasamosir & 661 & \\
\hline
\end{tabular}

BPS, 2014.

areal paling luas yaitu $72.337 \mathrm{~m} 2$ khususnya di Kecamatan Kisaran,realita tersebut memberikan ilustrasi bahwa areal Perkebunan Inti Rakyat di Kecamatan Kisaran memiliki luas paling tinggi artinnya para petani di wilayah yang bersangkutan perlu diberdayakan secara intensif agar supaya dapat meningkatkan produktivitasnya. Demikian pula Labuhan Batu Utara yang menjadi urutan kedua yaitu 68.161danLangkat urutan ketiga yaitu 45.413 yang luas wilayahnya lebih kecil jika dikomparasikan dengan Kabupaten Asahan, juga memerlukan pemberdayaan yang lebih berarti, menyusul wilayah lain di Sumatera Utara. Luasnya areal perkebunan Inti Rakyat (PIR) di Kecamatan Kisaran diiringi oleh rendahnya motivasi parapetani untuk meningkatkan produksi.Rendahnya motivasi para petani sejalan dengan pendapatnya Setiadi dan Kolip (2011:842) bahwa hasil aktivitas bertani masyarakat secara tradisional hanya digunakan untuk kebutuhan sehari-hari. Artinya hasil panen yang didapat dari bercocok tanam tidak menjadi komoditas perdagangan. Para petani dalam membudidayakan lahan hanya sebagai gaya hidup dan bukan bertani menjadi mata pencaharian, sehingga aktivitasnya dalam bertani tidak ada motivasi untuk meningkakan produksi.

Pada pertanian rakyat, masyarakat mengolah lahan perkebunan dengan cara tradisonal yang diwariskan dari generasi sebelumnya, sehingga mereka bertani belum maksimal. Terlebih lagi mereka melakukan aktivitas di perkebunan hanya sebagai penunjang kegiatan pokok. Aktivitas para petani melakukan kegiatan di lahan mereka hanya ditujukan untuk memenuhi kebutuhan hidup para petani dan tidak untuk memenuhi kebutuhan masyarakat secara keseluruhan, sehingga hasil keuntungan petani dari hasil pertanian tradisional tidak tinggi, bahkan ada yang sama sekali tidak ada hasil produksi perkebunanyang memadai. Sama seperti hasil penelitian Bellemare (2012) yang menunjukan bahwa pertanian tradisional berdampak positif dalam meningkatkan pendapatan rumah tangga petani.Menurut Syamsurizal(2009 :20-21) mengatakan bahwacampur tangan pemerintah terbatas pada pengaturan, pengendalian, disamping pelayanan dan pemberian kemudahan ataupun bantuan sarana penunjang yang diperlukan khususnya bagi masyarakat petani peserta.Hasil produksi yang belum memadai tersebut disebabkan karena tidak diusahakan dengan cara yang benar.Aktivitas perkebunan rakyat masih menggunakan tenaga kerja yang banyak. Penggunaan tenaga kerja yang banyak tersebut, dikarenakan masih minimnya teknologi, sehingga hanya menggunakan Sumber Daya Manusia(SDM) yang ada. Anggota keluarga juga menjadi potensi tenaga kerja yang digunakan,karena cara pandang para petani lebih mementingkan beraktivitas di lahan perkebunan ketimbang mengenyam pendidikan di sekolah, Akibatnya Kemiskinan rumah tangga petani digambarkan adanya lingkaran setan yang tidak kunjung dapat teratasi oleh petani. Padahal jika petani menggunakan teknik pertanian modern maka produktifitas pertanian meningkat dan pendapatan petani pun meningkat pula (Rutherford et all, 2016).Pendapatan yang rendah disebabkan oleh produktivitas lahan yang rendah, teknologi yang rendah dan kemampuan pernbiayaan yang rendah menyebabkan produksi dan produktivitas yang rendah, dan akhirnya kembali kepada pendapatan yang rendah (Bangun, $2010: 30$ ).

Kondisi seperti ini mencerminkan bahwa sistem pertanian tradisional masih tergantung dengan sumber tenaga kerja manusia yang ada. Selain itu, tata cara dalam pengolahan perkebunan rakyat juga masih menggunakan modal yang terbatas. Penggunaan modal yang terbatas didasari oleh areal perkebunan rakyat tidak luas yang penggunaan modal hanya sebatas pembelian pupuk perkebunan, sehingga perkebunan yang diusahakan rakyat masih jauh dari orientasi ekonomis yang mengharapkan keuntungan. Dalam penelitian yang dilakukan Ofuoko dan Unuetaraagbamu (2016) dan Wuepper and Sauer (2016) ditemukan bahwa para petani kecil tidak berdaya untuk mengelolah lahan mereka karena ketiadaan modal pengetahuan mengenai cara bertani yang efisien dan menguntungkan sehingga mereka hany mengelolah secara tradisional dan dengan hasil yang kecil.

Beranjak dari dua sinyalemen yang mengilustrasikan realita tersebut terdapat beberapa permasalahan mendasar berkaitan dengan sumber daya manusia dan sumber daya alam yang belum memadai. Permasalahan dalam lingkup sumber daya manusia memerlukan konsolidasi melalui pemberdayaan, sehingga peningkatan produksi di perkebunan inti rakyat dapat direalisasikan. Dengan demikian dari beberapa permasalahan yang ada dapat diformulasikan konseptual pertanyaan, bagaimana pemberdayaan sosial ekonomi berbasis pekebunan inti rakyat di wilayah Kecamatan Kisaran, Kabupaten Asahan?

Pemberdayaan merupakan serangkaian kegiatan untuk dapat memperkuat kekuasaan atau keberdayaan kelompok lemah dalam masyarakat, termasuk individu-individu yang mengalami masalah kemiskinan. Pemberdayaan dapat diartikan sebagai tujuan dan proses Sebagai tujuan, maka pemberdayaan menunjuk pada keadaan atau hasil yang ingin dicapai oleh sebuah perubahan sosial yaitu masyarakat yang berdaya, memiliki kekuasaan atau mempunyai pengetahuan dan kemampuan dalam memenuhi kebutuhan hidupnya baik yang bersifat fisik ekonomi, maupun sosial seperti memiliki kepercayaan 
diri, mampu menyampaikan aspirasi, mempunyai mata pencaharian, berpartisipasi dalam kegiatan sosial, dan mandiri dalam melaksanakan tugas-tugas kehidupannya (Suharto, 2009 :15; Erwiantono danSaleha, 2012:60). Defenisi tersebut diatas didukung dengan konsep pemberdayaan dari Fernandez (2015) Pemberdayaan sebagai upaya memberikan otonomi, wewenang, dan kepercayaan kepada setiap individu dalam suatu organisasi, serta mendorong mereka untuk kreatif agar dapat menyelesaikan tugasnya sebaik mungkin.

Beberapa elemen dalam pemberdayaan sebagai tujuan yang dikemukakan Suharto(2009), salah satunya berpartisipasi dalam kegiatan sosial yang merupakan manifestasi dari solidaritas. Merujuk buku teori sosiologi modern menjelaskansolidaritas sosial merupakan ikatan secara bersama kelompok yang menunjukkan suatu keadaan hubungan antara individu atau kelompok yang didasarkan pada persamaan moral, kolektif yang sama, dan kepercayaan yang dianut serta yang diperkuat oleh pengalaman emosional (Ritzer dan Goodman, 2014 :22). Butir-butir pengertian dalam solidaritas sosial terdapat beberapa ciri atau karakteristik yang mengilustrasikan bagi masyarakat bersahaja, seperti masyarakat pedesaan, sehingga keberadaan solidaritas sosial tersebut memiliki berbagai macam bentuk, di antaranya:

a. Dalam masyarakat agraris tradisional, terkadang melakukan pertukaran tanah dengan tenaga kerja.

b. Pancen yaitu bantuan tenaga kerja yang siap bagi kepala desa.

c. Gugur Gunung yaitu suatu pekerjaan secara bersama-sama tanpa dibayar.

d. Punjungan yaitu memberi bantuan atau hadiah, menukarkan barang dengan barang.

Butir-butir pengertian dan ciri-ciri dalam solidaritas, sejalan dengan pendapatnya Ibrahim (2008:32) solidaritas sosial adalah perasaan yang secara kelompok memiliki nilai-nilai yang sama atau kewajiban moral untuk memenuhi harapanharapan peran (role expectation). Pada umumnya solidaritas sosial merupakan trades secara terus menerus yang dijaga dari satu generasi ke generasi berikutnya dan dikawal ketat oleh kontrol sosial. Solidaritas sosial merupakan kekuatan persatuan internal dari suatu kelompok dan suatu keadaan hubungan antara individu atau kelompok yang didasarkan pada perasaan moral dan kepercayaan yang dianut bersama serta diperkuat pengamalan emosional bersama (Nasution, $2009: 7)$.

Keseluruhan kekuatan persatuan internal dalam solidaritas sosial juga dipengaruhi interaksi sosial yang berlangsung, karena ikatan kultural, yang pada dasarnya disebabkan munculnya sentimen komunitas, yang unsur-unsurnya menurut Ritzer \& Goodman, (2014 :22) meliputi: seperasaan, sepenanggungan, dan saling membutuhkan. Sesuai dengan pendapat di atas menurut Durkheim (dalam Samuel, 2010:15) solidaritas sosial memiiki berapa ciri dengan tingkat pembagian kerja yang rendah/soliaritas mekanik masih terikat satu dengan lain atas dari emosional dan kepercayaan serta komitmen moral. Dalam solidaritas mekanis, nilai dan norma bersifat umum, dan abstrak, hukum yang berlaku bersifat represif.

Solidaritas mekanik adalah ikatan sosial berdasarkan nilainilai moral dan sentimen bersama dan masih kuat dianut serta dipatuhi oleh para anggota masyarakat. Solidaritas mekanik sekaligus merupakan produk kesamaan struktur, okupasi, dan proses sosial dalam masyarakat dengan memiliki Rasa kebersamaan atau ungkapan perasaan pada sebuah kelompok untuk kepentingan bersama (Tarmuji danLestari (2014).dalam masyarakat yang dibentuk oleh solidaritas mekanik, kesadaran kolektif melingkupi seluruh anggota masyarakat (Nuryanto, 2014 :57). Solidaritas mekanik sangat diyakini sangat rigit, dan isinya sangat bersifat religius. Misalnya pada masyarakat pra-industrial, tradisi bertindak sebagai perekat sosial (kohesi) dalam masyarakatnya, karena terdapat tradisi mengembangkan solidaritas mekanik. Sejalan dengan solidaritas, elemen lain dalam pemberdayaan menurut Suharto (2009) adalah :

a. Empowering adalah penguatan pengetahuan dan kemampuan yang dimiliki masyarakat dalam memecahkan masalah dan memenuhi kebutuhan-kebutuhannya. Pemberdayaan harus mampu mengembangkan segenap kemampuan dan kepecayaan diri masyarakat yang menunjang kemandirian, salah satunya melalui pelatihan dan pendidikan. Konteks pendidikan yang dimaksud secara sosiologis adalah bagaimana individu melakukan transformasi nilai-nilai dalam mengajarkan masyarakat untuk dapat memenuhi kebutuhannya sebagai mahluk individu dan makhluk sosial (Durkheim dalam Hidayat, $2014: 85-86)$.

b. Supporting yaitu pemberian bimbingan dan dukungan kepada masyarakat lemah agar mampu menjalankan peran dan fungsi kehidupannya. Pemberdayaan harus mampu menyokong masyarakat agar tidak terjatuh ke dalam situasi yang semakin lemah dan terpinggirkan. Perlunyabimbingan terhadap masyarakat dilakukan melalui sosialisasi. Sosialisasi yang dilakukan dengan benarmaka akan melahirkan penguatan dalam masyarakat itu sendiri.

Literatur lain, Ferdinand Tonnies (Caya, 2015), mengelompokkan solidaritas atas gemeinschalf dan juga gesselschalf. Dimana gemeinschalf merupakan bentuk kehidupan yang intim sehingga solidaritas yang dibentuk lebih alami. Sedangkan, gesselschalft merupakan kehidupan publik yang terdiri atas orang-orang yang kebetulan hadir bersama tetapi bersifat sementara dan semu sehingga solidaritas yang dibentuk tidak tahan uji.

Proses berlangsungnya permberdayaan melalui solidaritas, penguatan pengetahuan dan bimbingan atau pelatihan dapat menumbuhkan motivasi. Menurut Sudrajat (2008) dan Kim,dkk (2011 :98) motivasi adalah sebagai kekuatan seseorang yang dapat menimbulkan tingkat persistensi dan antusiasmenya dalam melaksanakan suatu kegiatan, baik yang bersumber dari dalam diri individu sendiri (motivasi intrinsik) maupun dari luar individu (motivasi ekstrinsik).Motivasi yang bersifat intrinsik adalah manakala sifat pekerjaan itu sendiri yang membuat seorang termotivasi, orang tersebut mendapat kepuasan dengan melakukan pekerjaan dan bukan karena rangsangan lain, seperti status ataupun uang atau bisa juga dikatakan seorang melakukan hobbynya.Dalam pada itu motivasi ekstrinsik adalah manakala elemen-elemen di luar pekerjaan yang melekat pada pekerjaan tersebut menjadi faktor utama yang membuat seorang termotivasi seperti status ataupun kompensasi. Bentuk yang lain adalah memberikan hadiah atau bahkan hukuman merupakan salah satu langkah dalam memotivasi seseorang,sejalan dengan pendapat diatas Purwanto,dkk (2013) menegaskan motivasi instrinsik guru ekonomi sudah cukup baik, alaupun belum terpenuhi semua aspek. Selanjutnya motivasi ekstrinsik guru ekonomi sudah cukp baik hanya saja dalam metode belajar kurang adannya pengembangan.

Apabila seseorang merasa terancam, maka secara alamiah dirinya akan melakukan apapun dengan alasan keamanan dan kenyamanan. Demikian pula apabila seseorang melakukan 
sesuatu dengan tujuan mendapatkan hadiah, maka ia akan berusaha sekeras mungkin agar dapat memperoleh imbalan yang dimaksud. Realitas inilah yang kemudian menjadi dasar melakukan pemberdayaan dalam sebuah masyarakat yang warganya dalam cakupan perkebunan berskala kecil atau yang sering disebut dengan istilah perkebunan inti rakyat (PIR). Sejalan dengan hasil penelitian yang dilakukan Suandi,dkk, (2011 : 17) menggambarkan kelembagaan memiliki relasi yang signifikan terhadap pemberdayaan dan peningkatan masyarakat melalui program PIR.

Menurut Badrun (2010) pembangunan atau pengembangan masyarakat perkebunan kelapa sawit dengan pola perkebunan inti rakyat (PIR) ini pada dasarnya bertujuan untuk mencapai beberapa sasaran, antara lain:

1. Meningkatkan pendapatan masyarakat yang berpendapatan rendah melalui keikutsertaannya sebagai pemilik kebun plasma dengan harapan mampu menerapkan teknologi yang sesuai sehingga kebunnya berada pada tingkat produktifitas yang tinggi.

2. Sebagai upaya pendistribusian kekayaan nasional kepada masyarakat, melalui pendistribusian kredit untuk pembangunan kebun, dan pendistribusian lahan melalaui pemberian sertifikat tanah.

3. Sebagai upaya penyebaran pembangunan ke berbagai wilayah baru yang belum terjamah pembangunan teristimewa daerah terpencil dengan prasarana yang sangat tidak memadai sekaligus berperan sebagai pusat pertumbuhan.

4. Memadukan perusahaan besar sebagai inti dari perkebunan rakyat sebagai plasma untuk mentransfer teknologi dan

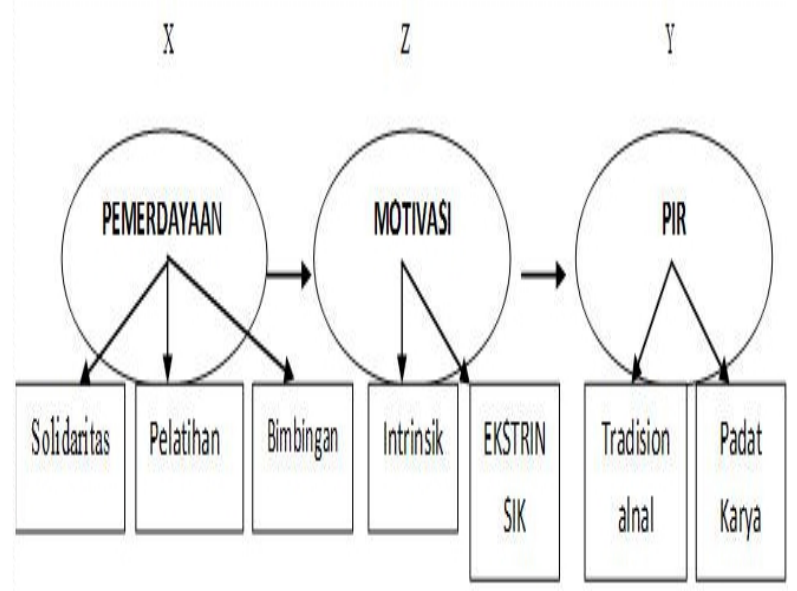

pertumbuhan kelembagaan-kelembagaan baru dikalangan masyarakat yang lebih maju.

Dengan demikian, secara visual bagan alur pemberdayaan sosial ekonomi perkebunan inti rakyat (PIR)dapat digambarkan sebagai berikut:

Dalam kajian sosiologis, perubahan sosial dapat dilihat sebagai sesuatu yang dinamis dan tidak linear. Perubahan sosial secara umum dapat diartikan sebagai suatu proses pergeseran atau berubahnya suatu tatanan didalam masyarakat, meliputi pola pikir yang lebih kreatif, sikap, serta kehidupannya sosialnya untuk mendapat kehidupan yang lebih baik (Munthe, 2007). Dalam proses pemberdayaan sudah pasti menimbulkan suatu perubahan sosial pada kelompok atau masyarakat yang diberdayakan seperti perubahan dari aspek sosial, aspek ekonomi maupun aspek politik. Perubahan sosial itu sendiri bisa menciptakan dampak negatif maupun dampak positif bagi masyrakat, tergantung seperti apa situasi perubahannya.

\section{METODE PENELITIAN}

Penelitian ini menggunakan metode penelitian kualitatif dengan jenis pendekatan studi kasus. Paradigma yang dipilih yaitu paradigma interpretif. Informan penelitian adalah para petani perkebunan. Adapun lokasi penelitian ini adalah di Kecamatan Kisaran Kabupaten Asahan, Sumatera Utara. Alasan pengambilan lokasi penelitian adalahbahwa populasi warga masyarakat yang beraktivitas dalam perkebunan inti rakyat(PIR) memiliki jumlahnya cukup besar dan memudahkan untuk mengimplementasikan program pemberdayaan sosial ekonomi di wilayah tersebut.

\section{Profil Informan}

Informan dalam penelitian ini adalahpenduduk desadi Kecamatan Kisaran, Kabupaten Asahan, karena anggota masyarakat di daerah ini memiliki areal Perkebunan Inti Rakyat (PIR) yang perlu diberdayakan serta menjadi sasaran pembangunan. Alasan lain yang mendasari dipilih daerah Kisaran, karena sebagian besar penduduk terdiri dari berbagai usaha kecil atau perkebunan inti rakyat (PIR). Sementara itu beberapa fenomena yang terjadi di wilayah tersebut, masih ada masalah yang belum diangkat dan dipelajari secara ilmiah yang difokuskan pada aspeksosialekonomi.

\section{Teknik Pengumpulan Data}

a. Observasi, merupakan teknik alat bantu, sebab sangat dimungkinkan ada realitas sosial yang tidak dapat ditangkap melalui teknik kuesioner, sehingga perlu interpretasi dari subjek peneliti. Observasi adalah teknik pengumpulan data dengan menggunakan indera mata dan analisis pikiran, dengan demikian teknik ini menuntut keluasan cakrawala konsep dan teori peneliti pada saat menginterpretasikan temuannya. Dalamitem itu observasi digunakan apabila penelitian berkenaan dengan perilaku manusia,proses kerja, gejala-gejala alam dimana responden yang diamati tidak terlalu besar (sugiyono,2007)

b. Interview mendalam (depth interview), dipergunakan pada saat mengejar jawaban yang dalam kategori raguragu. Jadi wawancara ini bersifat mengorek konsistensi antara sikap, perilaku dan nilai-nilai yang menjadi acuan.

c. Penghayatan (Einfuehlen), suatu teknik pengumpulan data melalui pendalaman bangunan berfikir dari responden. Teknik ini juga berupaya memahami kesadaran warga masyarakat berdasarkan logika kultur, dimana responden merupakan anggotanya.

\section{Interpretasi Data}

Keseluruhan data dan temuan-temuan lain yang telah diproleh melalui beberapa teknik pengumpulan data yakni observasi, wawancara mendalam dan penghayatan diinventarisir 
untuk dievaluasi. Prosesnya adalah dibaca, diedit kembali, dikategorikan, sehingga tersusun secara sistematis supaya lebih mudah dipahami. Langkah selanjutnya adalah melakukan pengolahan, analisis, telaah dan dirujukan dengan teori yang telah dikonseptualisasikan. Langkah lebih lanjut serangkaian tahapan mulai dari hasil pengolahan, analisis, dan telaahannya diinterpretasikan dan dideskripsikan secara kualitatif sesuai dengan metode penelitian yang sudah ditetapkan.

\section{HASIL DAN PEMBAHASAN}

Pada dasarnya dalam kajian sosiologis, pemberdayaan masyarakat adalah meningkatkan mobilitas sosial dari yang kurang aktif menuju yang lebih aktif. Dalam makna yang mendekati kesamaan pemberdayaan masyarakat adalah upaya untuk meningkatkan harkat dan martabat lapisan masyarakat yang dalam kondisi tidak mampu melepaskan diri dari perangkap kemiskinan dan keterbelakangan.Pemberdayaan pada intinya membahas bagaimana individu, kelompok atau komunitas berusaha mengontrol kehidupan mereka sendiri dan mengusahakan untuk membentuk masa depan sesuai dengan keinginan mereka (Ratna,dkk, 2012 :149). Tentu saja keinginan mereka tidak menunjukan distribusi yang homogen, sehingga orientasi untuk memperbaiki kondisi kehidupan, langkah-langkahnya sangat bervariasi.

Salah satu model pemberdayaan sesuai dengan permasalahan yang dihadapi oleh masyarakat di Kecamatan Kisaran adalah sosial ekonomi berbasis pada sektor perkebunan. Pelaksanaan pemberdayaan sosial ekonomi melalui soidaritas atau kerjasama dengan agent of change, yakni penguatan pengetahuan dan bimbingan yang merupakan model pengentasan kemiskinan pedesaan. Sebab kemiskinan mempengaruhi satu miliar penduduk dunia dan banyak diantara adalah masyarakat pedesan (Dlamini, 2014). Dengan Bekerjanya pemberdayaan melalui solidaritas dan agent of change diharapkan dapat mengatasi masalah kelangkaan Sumber Daya Manusia (SDM) yang berkualitas untuk meningkatkan produski perkebunan.

\section{Pemberdayaan Masyarakat di Kecamatan Kisaran, Kabupaten Asahan dengan Solidaritas atau Kerja Sama}

Pemberdayaan berbasis sektor perkebunan sesuai dengan permasalahan yang dihadapi dan jawaban yang dibutuhkan masyarakat di Kecamatan Kisaran, Kabupaten Asahan adalah konsolidasi sosial ekonomi, sehingga masyarakat dapat memenuhi keinginan dan kemandirian. Dalam upaya memanifestasikan pemberdayaan sosial ekonomi tersebut senantiasa mengedepankan kerja sama. Dalam hal ini kerja sama dimaksudkan sebagai suatu usaha bersama antara orang perorangan atau kelompok untuk mencapai tujuan bersama. Kerja sama dilakukan karena adanya interaksi dengan sesamanya. Kerja sama berawal dari kesamaan orientasi. Kerja sama akan terus berkembang apabila orang dapat digerakkan mencapai suatu tujuan bersama dan harus ada kesadaran bahwa tujuan tersebut dikemudian hari mempunyai manfaat bagi semua. Kerja sama dapat bersifat agresif apabila individu atau kelompok dalam jangka waktu lama mengalami kekecewaan sebagai akibat rasa ketidakpuasan karena keinginan pokoknya tidak dapat terpenuhi karena adanya rintangan yang bersumber dari luar kelompok itu (Soekanto, 2009 :50). Ada beberapa bentuk kerja sama yakni solidaritas, gotong royong, tawar menawar (bargaining), co-optation, koalisi dan patungan atau join venture.

Bentuk kerja sama yang terjalin antar sesama anggota dapat terlihat dari pembagian tugas yang telah diberikan kepada masing-masing anggota. Dalam penyelesaian tugas harian seperti mengelola ladang dan kebun sesuai jadwal yang telah ditentukan. Dalam kegiatan kerjasama anggota kelompok menggunakan panduan teknis untuk pemberdayaan perkebunan.

Kerja sama juga terjalin antar anggota kelompok yang merupakan penggerak membudidayakan perkebunan memiliki tujuan untuk meningkatkan pendapatan. Bentuk kerjasama yang terlain dapat terlihat dari beberapa aktivitas yang diberikan kepada anggota kelompok khususnya pada anggota kelompok yang masih aktif. Setiap bulan secara bergiliran anggota kelompok memiliki kesempatan untuk mengelola kebun dan bagaimana tanaman dapat tumbuh dan berkembang dengan baik.

Dalam penelitian yang dilakukan oleh Sianipar and Widaretna (2012) mengenai pemberdayaan petani kakao di Nias ditemukan data bahwa masyarakat khususnya petani kakao melakukan kerjasama dengan pihak-pihak steakholders terkait untuk meningkatkan produktifitas kakao. Hasilnya, dengan adanya kerja sama produktifitas kakao meningkat dan seiring meningkatkan pendapatan petani. Keuntungan yang lain, Petani juga diberikan pelatihan dan pengetahuan mengenai dan pengetahuan mengenai teknik pengelolaan yang baik. Maka dari pada itu, kerjasama merupakan elemen yang penting dalam proses pemberdayaan individu maupun kelompok.

\section{Pemberdayaan Melalui Agent of Change}

Pemberdayaan masyarakat melalui agent of change yang terdapat di Kecamatan Kisaran, tidak terlepas dari peran aktif masyarakat, kepala desa maupun kepala dusun yang mewakili dari masyarakat setiap dusun yang bersama-sama mendiskusikan permasalahan, khususnya masalah perkebunan yang ada di wilayahnya, sehingga kebutuhan masyarakat terpenuhi dan permasalahan perkebunan dapat diselesaikan. Pemberdayaan yang dilakukan oleh agent of change di Kecamatan Kisaran merupakan pemberdayaan masyarakat yang bersifatTop-down. Pemberdayaan masyarakat yang bersifat Top-down, pelaksanaannya ditentukan oleh pusat, seperti penempatan hasil perkebunan yang diletakkan di satu tempat di rumah ketua kelompok, sehingga kreativitas masyarakat untuk meningkatkan pengetahuan dan keterampilan dalam pengurusan bibit dan hasil dapat terkikis. Dengan pemberdayaan dan semua ketentuan pelaksanaannya ditentukan oleh pusat telah mengakibatkan masyarakat terinternalisasi oleh kebiasaan menunggu petunjuk dari pemerintah. Kurangnya sosialisasi dan pemahaman tentang bagaimana suatu program harus dilaksanakan, namun masyarakat sudah diserahi sepenuhnya dalam perencanaan yang menimbulkan ketidaksiapan psikologis masyarakat (Imama \& Parwata, 2014 :16).

Kebijakan pemerintah untuk menempatkan hasil perkebunan tersebut di satu tempat sangat bertentangan dengan apa yang diinginkan oleh masyarakat. Karena masyarakat menginginkan hasil perkebunan tersebut diurus oleh masing-masing anggota kelompok dan dibuat kompetisi, sehingga kinerja masyarakat dalam pemberdayaandapat meningkat. Oleh karena kebijakan yang dibuat oleh pemerintah tersebut menyebabkan inisiatif dan kemandirian masyarakat semakin terkikis,maka memunculkan ketergantungan masyarakat terhadap bantuan pemerintah. Kasus ini sama dengan penelitian Abebe et al (2013) bahwa petani cenderung meminimalisir mengambil resiko dengan hanya mengharapkan partisipasi dari pemerintah ataupun swasta untuk telibat dalam pengelolahan pertanian. Dengan pendekatan top-down ini masyarakat belum berperan sebagai pelaku utama dalam kegiatan pemberdayaan yang diberikan pemerintah, karena dominasi pemerintah dalam kegiatan 
tersebut, tak jarang membuat masyarakat menjadi penonton. Akan tetapi, dalam kondisi tertentu pemberdayaan melalui agent of change dengan pendekan Top Down terdapat beberapa inovasi-inovasi baru yang masuk ke dalam putaran interaksi para anggota masyarakat yang operasionalnya melalui sosialisasi.

Menurut Peter Berger sosialisasi merupakan proses dimana seseorang belajar menjadi anggota yang berpatisipasi dalam masyarakat. Proses sosialisasi ini dapat dilakukan melalui sosialisasi ekualitas. Sosialisasi ekualitas dilakukan oleh orang-orang yang memiliki kedudukan sederajat dengan mereka yang disosialisasikan, walaupun dalam sosialisasi seperti ini diperlukan juga adanya pemahaman atas normanorma sosial kepada ingatan individu yang disosialisasikan, namun tujuan utama dari proses sosialisasi ekualitas ini adalah agar individu yang disosialisasikan itu dapat diajak bekerja sama yang koordinatif dan kooperatif dengan pihak yang mensosialisasi ( Setiadi\&Kolip, 2011:155).

Sosialisasi ini juga diperlukan dalam suatu program pemberdayaan masyarakat, seperti agent of change yang ada di Kecamatan Kisaran, karena dengan adanya sosialisasi yang diberikan agent of change kepada masyarakat, di Kecamatan Kisaran dapat mengetahui program agent of change. Sosialisasi yang dilakukan oleh agent of change adalah sosialisasi langsung dan sosialisasi tidak langsung. Sosialisasi program agent of change di bidang perkebunan pertama kali dilakukan pada tanggal 31 juli 2009. Target yang diinginkan dalam sosialisasi ini adalah memperkenalkan program agent of change kepada masyarkat di Kecamatan Kisaran, khusunya masyarakat yang memiliki perkebunan dan lahan. Sosialisasi yang dilakukan oleh agent of change juga memperkenalkan teknologi tepat guna yang berbasis perkebunan yakni penggarapan lahan kebun secara efektif dan memadai.

Proses berlangsungnya sosialisasi yang dilakukan oleh agent of changememberikan bimbingan tentang pembudidayaan perkebunan. Akibatnya, terjadi transfer ilmu pengetahuan dari agent of change terhadap anggota kelompok pembudidayaan perkebunan yang masih aktif. Implementasi dari hasil penelitian lain bahwa pemberdayaan menginginkan pengembangan modal manusia dan akan lebih baik lagi jika pemberdayaan didukung oleh pengembangan kemampuan pelaku pemberdayaan (Widjajanti, 2011: 15-27). Agent of change juga membantu anggota kelompok yang sedang bertugas, seperti membersihkan lahan dan memberi memberi pupuk tanaman tersebut, sehingga pekerjaan yang diemban oleh anggota kelompok yang sedang beraktifitas semakin berkurang, karena adanya bantuan yang dilakukan oleh agent of change.

Adanya agent of change pada masyarakat di Kecamatan Kisaran, telah memberikan manfaat bagi masyarakat yang memiliki orientasi untuk melakukan konsolidasi kehidupan. Pemberdayaan masyarakat bukanlah membuat seseorang menjadi objek, melainkan sebagai aktor atau pelaku yang dapat menentukan kehidupan mereka sendiri. Manfaat dari adanya agent of change ini juga memberikan pemahaman kepada masyarakat atau mentransformasi nilai kepada masyarakat bahwa dengan adanya agent of change, masyarakat mengetahui bahwa dalam setiap kegiatan yang akan dilaksanakan itu harus ada perencanaan sampai tahap pengevaluasian. Masyarakat yang bekerja sebagai petani yang masih aktif juga merasakanmanfaat dengan mendapatkan ilmu pengetahuan tentang perkebunan, terutama caracara meningkatkan produktivitas hasil perkebunan. Hasil penelitian lain yang dapat dirujukan sebagai penguatan adalah pemberdayaan sosial ekonomi keluarga berhasil dalam meningkatkan pendapatan keluarga atau pemberdayaan usaha produktif petani tradisional berhasil meningkatkan pendapatan rumah tangga petani (Rahim; Tahir; Rumbia, 2014).

Manfaat yang dirasakan dan diterima oleh anggota kelompok yang masih aktif, tidak serta merta dirasakan oleh anggota kelompok yang tidak aktif lagi. Anggota kelompok petaniatau pekebunyang tidak aktif tidak merasakan manfaat apapun dari kegiatan pemberdayaan yang mereka ikuti beberapa bulan. Adapun beberapa manfaat yang dirasakan oleh anggota masyarakat yang masih aktif dalam kegiatan pemberdayaan terebut adalah:

1. Diajarkan tentang meningkatkan produksi tanaman perkebunan setiap bulannya, sehingga anggota yang masih aktif sekarang sudah mulai mengetahui bagaimana cara meningkatkan produksi tanaman-tanaman mereka.

2. Agar masyarakat di Kecamatan Kisaran bisa sharing dan kerja sama untuk pengembangan usaha di bidang perkebunan dan dapat mempersatukan masyarakat, terutama masyarakat yang ikut dalam kelompok pemberdayaan, maka masyarakat itu semakin kuat rasa solidaritasnya.

3. Dapat menambah penghasilan apabila sudah ada penjualan, karena hasil penujualan nantinya akan dibagibagi kepada anggkota kelompok yang masih aktif.

4. Memperoleh ilmu pengetahuan di bidang perkebunan.

Dalam pemberdayaan masyarakat yang sesuai dengan konsep yang dirancang untuk kemakmuran petani dalam mengembangkan perkebunan di pedesaan, Syahza (2007 :25) bahwa pemberdayaan itu proses yang berjalan terus menerus yang dapat memberikan dan meningkatkan kemampuan masyarakatuntuk keluar dari kelemahannya. Para anggota masyarakat yang merasa mendapatkan manfaat memiliki keinginan untuk tetap maju atau termotivasi.Friss- Hansen dan Duveskog (2012) membuktikan bahwa dampak yang paling nyata dari proses pemberdayaan adalah para petani dan penduduk setempat dapat membuat pilihan-pilihan dan keputusan-keputusan untuk meningkatkan inovasi pertanian. Dalam proses pemberdayaan itu petani juga diajarkan menggunakan teknologi tepat guna, sehingga dengan itu dapat mencapai pembangunan yang berkelanjutan di masyarakat (Sianipar et all, 2013).

\section{Peningkatan Motivasi para Anggota Masyarakat}

Dalam proses perkembangan peradaban para anggota masyarakat telah mengalami pelebaran cakrawala yang didapatkan dari meningkatnya jalinan interaksi yang datang dari luar komunitasnya. Sikap para anggota masyarakat yang telah banyak mengadopsi nilai-nilai sosial baru mengindikasikan cepatnya mobilitas sosial dan psikis untuk mengindentifikasikan diri dengan pihak lain yang dianggap memiliki kelebihan daripada dirinya. Saluran bertindak (line of action) para anggota komunitas dalam masyarakat dapat disimak dari meningkatnya frekuensi aktifitas dalam aspek-aspek kehidupannya, sehingga untuk jangka panjang aktifitasnya ada tendensi berlangsung secara kesinambungan. Realita tersebut termanifestasikan dalam kemapuannya melihat potensi diri dengan tolok ukur dari luar lingkungannya, membandingkan situasi internal komunitasnya dengan mendasarkan diri pada keadaan eksternalnya. Proses komparasi ini berakibat pada tumbuhnya sikap instropeksi diri, salah satunya membandingkan keadaan diri dengan keadaan di luar, sehingga sebagai akibat lanjutannya tidak jarang 
meningkatkan derajat empati para anggota komunitas yang diiringi dengan meningkatnya motivasi.

Dewasa ini, para anggota masyarakat yang mensinyalir tingkat motivasi terhadap pembangunan wilayah yang bertujuan memberdayakan komunitas, meningkatkan sumber daya manusia, meningkatkan sarana dan prasarana sumber daya alam dan meningkatkan status sosial ekonomi, yang direalisasikan melalui peningkatan kesejahteraan. Demikian pula para anggota masyarakat di Kecamatan Kisaran yang memiliki tingkat motivasi terhadap pemberdayaan sosial ekonomi yang berbasis Perkebunan Inti Rakyat (PIR) menyampaikan beberapa pernyataan yang bervariasi. Motivasi itu sendiri terbentuk dari kebutuhan manusia dan pada dasarnya seseorang terlebih dahulu harus mengetahui apa yang diinginkan dan dibutuhkan sehingga nantinya dapat mengatur rencana untuk mencapainya (Lundberg and Lidelow, 2015).

Beberapa modal dasar yang kami dapatkan melalui sosialisasi seperti bimbingan, penguatan pengetahuan dan pelatihan memberikan kontribusi yang sangat berarti untuk meningkatkan aktivitas membudidayakan perkebunan. Karena konsekuensi dari aktifitas yang didasari oleh modal dasar yang kami terima, dalam kondisi minimal ada dorongan untuk mengembangkan kehidupan yang lebih baik lagi.Sebelum kami menerima butir-butir sosialisasi pengarahan, beberapa teknis untuk membudidayakan perkebunan,cara yang kami gunakan hanya berdasarkan petunjuk yang diwariskan dari satu generasi ke generasi berikutnya. Dengan demikian, apabila teknik pembudidayaan perkebunan berdasarkan dari elemen-elemen modal dasar yang didapat melalui sosialisasi dianggap lebih maju daripada tenik-teknik manual yang dipergunakan sebelumnya.

Para anggota masyarakat yang lain menyampaikan beberapa pernyataan yang berkaitan dengan motif-motif yang dimiliki. Pada era sekarang ini mencari aktifitas yang dapat mendapatkan ganjaran tidak gampang, mengingat persaingan semakin ketat. Para anggota masyarakat berusaha menghilangkan sikap pasif, sehubungan dengan perkembangan era yang semakin maju. Sikap pasif ini dapat menghambat pembangunan Sumber Daya Manusia itu sendiri (Quaedvlieg, 2014). Artinya akan mengerjakan apa saja yang bisa dikerjakan, asalkan langkahlangkahnya benar. Kehidupan di kampung yang statis seperti dahulu harus dirubah, karena kalau tidak segera dirubah, kehidupan tidak berkembang.

\section{Beberapa Kendala Internal dari Sebagian Para Anggota Masyarakat}

Pelaksanaanpemberdayaan yang dilaksanakan di Kecamatan Kisaran pada awalnya yang menjadi target adalah masyarakat yang memiliki perkebunan. Dalam hal ini agent of change selaku penggerak masyarakat memberikan pembinaan tentang perkebunan kepada masyarakat di Kecamatan Kisaran yang memiliki lahan perkebunan. Namun di dalam pencapaian target yang diinginkan peserta yang ikut dalam kegiatan tersebut tidak semuanya memiliki lahan.

Pemberdayaan yang dilakukan di Kecamatan Kisaran, Kabupaten Asahan, belum sepenuhnya sinkron dengan konsep pembangunan dan pemberdayaan masyarakat artinya pelaksanaan pemberdayaan tersebut belum sesuai dengan konsep pembangunan pedesaan dengan prinsip keterbukaan atau transparansi. Agent of change dalam memberdayakan masyarakat belum mencapai tujuannya yakni pemberdayaan tersebut belum dapat menciptakan kader pembangunan, karena belum dilakukannya tahap kemandirian dalam masyarakat, sehingga apabila kegiatan tersebut ditinggalkan oleh agent of change sebagai penggerak pembangunan desa tidak dapat berkelanjutan. Masyarakat yang sifatnya ingin tahu tentang program pemberdayaan ini mengalami gejolak karena apa yang diinginkan dalam pemecahan permasalahan yang dihadapi tidak sesuai dengan kenyataan yang terjadi pada pelaksanaan pemberdayaan.Sementara itu, Pemberdayaan ini dalam pelaksanaannya sampai sekarang belum mendatangkan keuntungan ekonomi bagi anggota kelompok, karena belum pembagian hasil usaha kepada anggota kelompok yang masih aktif.

Peranan masyarakat dalam suatu proses pemberdayaan merupakan indikator terpenting untuk menciptakan amsyarakat yang maju (Norman, 2015). Pelaksanaan pemberdayaan masyarakat di Kecamatan Kisaran, memiliki kesulitan di dalam mengajak masyarakat untuk ikut terlibat terhadap pengenalan pemberdayaan, khususnyabagi mereka yang tidak aktif. Masyarakat di Kecamatan Kisaran yang sifatnya individualis dapat menyulitkan agent of change di dalam melakukan musyawarah dengan masyarakat, kondisi alam juga menjadi kendala agent of change di dalam menjalankan kegiatan perkebunan ini, serta kurang adanya kerja sama antar anggota kelompok juga menyebabkan kegiatan perkebunan ini menjadi terkendala. Masyarakat di Kecamatan Kisaran yang lebih suka untuk bekerja sendiri-sendiri dari pada bekerja secara berkelompok. Sifat masyarakat yang merasa bahwa pengetahuan yang dimilikinya dalam perkebunan sudah cukup untuk meningkatkan produksi mereka, sehingga masyarakat merasa tidak memerlukan pembinaan serta pelatihan tentang pendidikan untuk dapat meningkatkan produksi perkebunan mereka. Adanya pola pikir masyarakat yang demikian, bukanlah hal yang mudah untuk dirubah. Karena cara tradisional yang dipakai masyarakat masih sangat berguna bagi keberlangsungan perkebunannya, maka masyarakat di Kecamatan Kisaran tidak perlu ikut pelatihan, karena dengan cara tradisional saja mereka dapat meningkatkan produksi perkebunan mereka.

Masyarakat yang tidak ikut serta lagi dalam kelompok tersebut tidak memperoleh keuntungan apapun, baik itu keuntungan materi dan keuntungan dalam bidang pendidikan mengenai perkebunan inti rakyat, walaupun merekamengeluarkan modal. Kenyataan ini berbeda dari keadaan yang dialami oleh anggota yang masih ikut dalam kelompok, mereka sudah mendapatkan pengetahuan tentang pemeliharaan, dan peningkatan hasil produksi perkebunan. Meskipun anggota yang masih aktif ini mendapatkan pendidikan dan pengetahuan tentang perkebunan, realisasinya keuntungan ekonomi belum mereka dapatkan. Keuntungan ekonomi dalam kegiatan perekebunan ini masih bersifat investasi, karena keuntungan dari hasil perkebunan tersebut belum dibagikan kepada anggota kelompok yang masih aktif.

\section{KESIMPULAN DAN SARAN}

Kondisi perkebunan inti rakyat di wilayah Kecamatan Kisaran belum memiliki sumber daya alam dan sumber daya manusia yang memadai. Agent of changesebagai salah satu konsepuntuk melakukan pemberdayaan sosial ekonomi masyarakat di wilayah Kecamatan Kisaran yang berbasis perkebunan inti rakyat (PIR). Pemberdayaan tersebut memberikan implikasi berupa penguatanpendampingan kepada masyarakat setempat secara langsung maupun tidak langsung sebagai salah satu daya gerak masyarakatuntuklebihproduktif. Oleh karenanya usaha pemberdayaan tersebut memuat tindakan penting (urgensi) yang dipraktikan melalui pelaksanaan pemberdayaan. 
Kesulitan dalam melakukan pemberdayaan masyarakat di Kecamatan Kisaran adalah karakteristik masyarakat di Kecamatan Kisaran bersifat individualis sehingga menyulitkan agent of changeberinteraksi dengan masyarakat. Lebih lanjut, kondisi alam yang kurang memadai menjadi kendala agent of change dalam menjalankan sosialisasi pemberdayaan serta kurangnya kerja sama antar anggota kelompok. Akibatnya, kegiatan perkebunan menjadi terhambat serta kecenderungan masyarakat di Kecamatan Kisaran lebih suka untuk bekerja secara mandiri (sendiri) dari pada bekerja secara kolektif.

\section{DAFTAR PUSTAKA}

Abebe,Gumataw K et.al. 2013. “ Contract Farming Configuration : Smallholders'Preferences for Contract Design Atributes". Journal of Food Policy, Vol. 40, pp. 14-24

Badrun, 2010.“Perusahan Inti Rakyat Perkebunan (PIR BUN) Kemitraan Usaha Dasar Dalam Agraris Perkebunan". Penerbit Garmedia. Jakarta

Bangun, 2010. "Pengembangan Sistem Integrasi Sapi dalam Peningkatan Pendapatan Petani Di Provinsi Riau”. Jurnal Teroka,Agustus 2010, Vol. 10, No.2, pp. 161174.

Bellemare, Marc F. 2012. “As You Sow, So Shall You Reap : The Welfare Impacts of Contract Farming". World Development Journal. Vol. 40. Issue 07, pp. 1418-1434.

Caya, Sinan. 2015. "Landsmann Solidarity among Turkish Citizens. Journal Social and Behaviorial and Sciences, Vol.190, pp.440-447.

Dlamini N.S et.al.c2014. "The CDAA Framework for Development of Sustainable Large-scale Smallholder Irrigation Schemes in Swaziland". Agriculture and Agricultural Science Procedia. Vol.2, pp. 386-393.

Erwiantono dan Saleha. 2012. "Persepsi dan Ekspetasi Pembangunan Masyarakat Terhadap Pemerintah Daerah dan Perusahaan Migas".Jurnal Makara Sosial Humaniora,Vol.16, No. 1, pp. 57-67.

Fernandez-Moral, M.J et.al. 2015. "Empowerment Evaluation In Spain: The Critical Friend Role in Working with Rural Communities". Journal Social and Behaviorial Sciences. Vol.191. pp. 984-989.

Friis-Hansen, E and Duveskog Deborah. 2012. "The Empowerment Route to Well-being: An Analysis of Farmer Field Schools in East Africa". World Development. Vol.40, Issue 2, pp. 414-427.

Herwati, 2011."Model Pemberdayaan Masyarakat Desa dan Penanggulangan Kemiskinan Melalui Pengembangan Desa Wisata di Depok". Jurnal Ekonomi dan Bisnis. Vol. 10, No. 2,pp. 168-175.

Hidayat, Rahmat. 2014. "Sosiologi Pendidikan". Penerbit Rajawali, Jakarta

Ibrahim Jabal, Tarik.2008. "Pembangunan Masyarakat Desa”, Penerbit UMM, Malang

Imama dan Parwata. 2014. "Dampak Sosial Ekonomi Perkebunan Teh Wonosari Terhadap Masyarakat Desa Toyomarto Kecamatan Singosari Kabupaten Malang Tahun 1996-2102”. Jurnal Publika Budaya, Vol. 2, No. 2,pp. 10-18.

Kim,et.al. 2011. "Social Networking Service : Motivation, pleasure, and behavioral, intentioun to use". The Journal of Computer Information Systems, Vol. 54, No. 4, pp. 92-101.

Lundberg, Mary and Lidelow, Helena. 2015. "Social Motivations for Knowlegde Sharing in Construction Companies". Journal Procedia Economics and Finance, Vol.21, pp. 224-230.
Munthe, Hardiana Marhaeni. 2007.” Modernisasi dan Perubahan Sosial Masyarakat Dalam Pembangunan Pertanian : Suatu Tinjauan Sosiologis”. Jurnal Harmoni Sosial,Vol.II, No.1, pp.1-7

Nasution, Zulkarnain. 2009. "Solidaritas Sosial dan artisipasi Masyarakat Desa Transisi”. Penerbit UMM, Malang.

Norman, David. 2015. "Transitioning From Faternalism to Empowerment of Farmers In Low-Income Countries: Farming components to systems". Journal of Integrative Agriculture, Vol.14, Issue 8, pp.1490-1499.

Nuryanto, Rahmat Budi. 2014. "Studi Tentang Solidaritas Sosial di Desa Modang Kecamatan Kuaro Kabupaten Paser (Kasus Kelompok Buruh Bongkar Muatan)”. Jurnal Sosiatri, Vol. 2, No.3,pp. 53-63.

Ofuoku, A and Unuetaraaagbanu, J. 2016. "Maize Contract Farming Experience In Delta State, Nigeria". Journal of Northeast Agricultural University (English Edition). Vol 23, Issue 01, pp 65-73.

Purwanto,Sri Eko, Budi Utomo Bambang. 2013.“Analisis Motivasi Instrinsik dan Ekstrinsik Guru Ekonomu SMAN 1 Mempawah Hulu Kabupaten Landak”.Jurnal Pendidikan dan Pembelajaran,Vol. 2, No. 5.

Quaedvlieg. 2014. "Is Amazon nut certification a solution for increased smallholder empowerment in Peruvian Amazonia?". Juornal of Rural Studies, Vol.33, pp. 4155.

Raharto, Sugeng. 2016. "Institutional Development Model Cocoa Farmers in East Java Province District Blitar". JournalAgriculture and Agricultural Science Procedia. Vol 9. Pp. $95-102$

Rahim, Manat; Tahir, Madjiani; Rumbia, Waly Aya. 2014. "Model Pemberdayaan Masyarakat di Wilayah Pesisir Dalam Menanggulangi Kemiskinan di Kabupaten Buton, Sulawesi Tenggara”. Jurnal The Winners, Maret 2014 Vol.15, No.1.

Ratna,dkk. 2012. "Pemberdayaan Petani Melalui Gabungan Kelompok Tani (Gapoktani)”.Jurnal Diklus,Vol. 16, No. 2,pp. 144-152.

Ritzer dan Goodman. 2014. "Teori Sosiologi Modern" (diterjemahkan oleh Alimandan). Penerbit Pranada. Jakarta

Rutherford, Diana Duff et all. 2016. "Impact of an Agricultural Value Chain Project on Smallholder Farmers, Households, and Children in Liberia". World Development, Vol.83, pp. 70-83

Samuel, H. 2010. "Emile Durkheim : Riwayat, Pemikiran, dan Warisan Bapak Sosiologi Modern”.Penerbit Kepig, Jakarta

Setiadi, M. Eli dan Kolip, Usman, 2011. "Pengantar Sosiologi”. Penerbit Kencana Prenada Media Group. Jakarta

Soekanto, Soerjono.2009. “Sosiologi Suatu Pengantar”. Raja Grafindo Persada: Jakarta.

Soenarto, Kamanto. 2014. "Pengantar Sosiologi". Penerbit LEFUI.Jakarta

Suandi,dkk. 2011. "Pemberdayaan Masyarakat Melalui Pengembangan Pertanian Organik Berbasis Trikomlitan di Kota Sungai Penuh Provinsi Jambi”. Jurnal Pengabdian Masyarakat, No. 52, pp. 13-20.

Sudrajat, Akhmad. 2008. "Teori-TeoriMotivasi". Diambil tanggal 25 Maret 2013 darihttps://akhmadsudrajat. wordpress.com/2008/02/06/teori-teori-motivasi/.

Sugiyono, 2007."Metode penelitian Kuantitatif dan $R \& D$ ALFABETA".Bandung

Suharto, Edi. 2009. "Membangun Masyarakat Memberdayakan Rakyat”. PT.Refika Aditama: Bandung.

Syahza,Almasdi.2007."Percepatan Pemberdayaan 
Ekonomi Masyarakat Pedesaan dengan Model AgroestateBerbasis Kelapa Sawit”.Jurnal Ekonomi, Vol.12, No.2.

Syamsurizal,2009. "Penelitian Skripsi UniversitasBengkulu. (tidak diterbitkan)". Bengkulu

Sianipar and Widaretna. 2012. "NGO as Triple-Helix Axis : Some Lessons from Nias Community Empowerment on Cocoa production". The Journal Social and Behaviorial Sciences, Vol. 52, pp. 197-206.

Sianipar Corinthias Pamatang Morgana et all. 2013. "Community Empowerment Through Appropriate Technology: Sustaining The Sustainable Development". Journal of Procedia Environmental Sciences, Vol.17, pp. 1007-1016.

Singh, Sonal and Bhowmich, Bhaskar. 2015. "An Exploratory Study for Conceptualization of Rural Innovation in Indian Context". Procedia- Social and Behavioral Sciences, Vol.207, pp. 807-815.
Tarmuji Achmad, Lestari Puji, 2014. "Peran Persatuan Solidaritas Kepala Desa dan Perangkat Desa Kabupaten Pati dalam MenyalurkanAspirasi Masyarakat".Unnes Civic Education Journal, Vol. 3, No. 1,pp. 62-70.

Widjajanti, Kesi. 2011."Model Pemberdayaan masyarakat". Jurnal Ekonomi Pembangunan,Juni 2011, Vol. 12, No. 1, pp. 15-27.

Wijaya Adi, Panji.2009.“Analisis Implementasi Program Perusahaan Inti Rakyat (PIR-BUN) Pada PTPN VII Unit Sluma di Kabupaten Bengkulu Tengah". Undergraduated thesis, Fakultas Ilmu Sosal dan Politik, UNIB

Wuepper, David and Sauer, Johannes. 2016. "Explaining The Performance of Contract Farming in Ghana: The Role of Self-Efficacy and SocialCapital”. Journal Food Policy, Vol. 62, pp. 11-27. 